\title{
Induction of suppressiveness to Fusarium wilt of chrysanthemum with composted sewage sludge
}

\author{
Zayame Vegette Pinto ${ }^{1}$, Marcelo Augusto Boechat Morandi² \& Wagner Bettiol ${ }^{2}$ \\ 'Departamento de Fitossanidade, Universidade Estadual Paulista "Júlio de Mesquita Filho", Cx. Postal 102, 18618-000, \\ Botucatu, SP, Brazil; ²Embrapa Meio Ambiente, Cx. Postal 69, 13820-000, Jaguariúna, SP, Brazil
}

Author for correspondence: Wagner Bettiol, e-mail: wagner.bettiol@embrapa.br

\begin{abstract}
The effectiveness of composted sewage sludge incorporated into Pinus bark-based substrate with or without biofertilizer, fish hydrolyzate, chitosan and Trichoderma asperellum was evaluated for the control of Fusarium wilt in chrysanthemum. The substrate was obtained from pots containing chrysanthemum plants killed by the pathogen. Half of the substrate was sterilized prior to the incorporation of sewage sludge $(0,10 \%, 20 \%$ and $30 \% \mathrm{v} / \mathrm{v})$. These substrates were or were not supplemented with the following: biofertilizer, fish hydrolyzate and Trichoderma. The mixtures were transferred to pots, and the chrysanthemum was transplanted. For all treatments, half of the plants were sprayed weekly with chitosan. Assessment of severity was performed on the $8^{\text {th }}, 12^{\text {th }}, 15^{\text {th }}$ and $20^{\text {th }}$ week after transplanting. In the $12^{\text {th }}$ week, microbiological and chemical analysis of the substrate was performed. The incorporation of composted sewage sludge into the Pinus bark-based substrate significantly reduced Fusarium wilt, which was progressively decreased as the concentration of sewage sludge increased. The addition of biofertilizer, fish hydrolyzate, chitosan and Trichoderma had no effect on the disease. The microbial community was greater in non-disinfested substrates. The results indicate that suppressiveness is related to the interaction of chemical and microbiological factors.
\end{abstract}

Key words: Chrysanthemum morifolium, biosolid, container media, organic matter, soil-borne pathogens

\section{INTRODUCTION}

The fungus Fusarium oxysporum f. sp. crysanthemi is the causal agent of wilt in chrysanthemum and, when present in the production system, may be responsible for losses of more than $50 \%$ (Pinto et al., 2010). This pathogen is difficult to control because there are no resistant varieties or registered fungicides. Furthermore, the pathogen produces chlamydospores that can survive for years in soil or substrate. Fusarium may also be present in irrigation water, in the pipe biofilms or in irrigation systems, further hindering its control. For chrysanthemums grown in pots containing substrates, the spread of the pathogen via water from the irrigation system is common. Therefore, to profitably produce plants, farmers must minimize the occurrence of the pathogen in the area by employing several management measures, such as the use of healthy seedlings, cleaning the irrigation systems, the use of a pathogen-free substrate and, if possible, the use of a suppressive substrate (Bettiol et al., 2009).

The substrates available on the market have general characteristics that make them conducive to Fusarium, such as acidic $\mathrm{pH}$, low microbial activity and low electrical conductivity, among others (Santos \& Bettiol, 2003; Amir \& Alabouvette, 1993). Thus, even if the substrate is free of the pathogen, when infested by routes such as seedlings or irrigation water, the pathogen will encounter favorable conditions for its development. Therefore, suppressive substrates should be developed to maintain the disease at levels below the economic damage threshold (Baker \& Cook, 1974; Bettiol et al., 2009).

An alternative for obtaining a suppressive substrate is the incorporation of organic materials in conducive commercial substrates, using the same principles described and studied for soil (Baker \& Cook, 1974; Hoitink \& Fahy, 1986; Bailey \& Lazarovits, 2003; Termoshuizen et al., 2006; Zmora-Nahum et al., 2008). Several residues containing organic matter, when incorporated into soil or substrate, are able to support greater microbial activity, greater aeration and moisture retention, provide macro- and micronutrients, growth hormones and amino acids, induce host resistance, produce toxic compounds to the pathogen and make soil chemical characteristics unfavorable to the pathogen, thus inducing suppressiveness (Hoitink \& Fahy, 1986; Hoper \& Alabouvette, 1996; Alabouvette, 1999; Conn \& Lazarovits, 1999; Tenuta et al., 2002; Bailey \& Lazarovits, 2003; Abassi et al., 2004; Blum \& Rodriguez-Kabana, 2004; Conn et al., 2005; Ureba et al., 2005; Termorshuizen et al., 2006; Yogev et al., 2006; Ghini et al., 2007; Zmora-Nahum et al., 2008; Lazarovits et al., 2009; Mendes et al., 2011). Specifically for the Fusarium-chrysanthemum pathosystem, a wood bark-based compost has been reported to induce suppressiveness (Chef et al. 1983). Pane et al. (2011) and Alfano et al. (2012) also provide evidence for induction of substrate suppressiveness in other pathosystems. 
Organic materials have particular characteristics that may or may not make the substrate suppressive to a particular pathogen (Termorshuizen et al., 2006). The induction of suppressiveness to Fusarium wilt by means of incorporating organic matter in the soil or substrate was demonstrated by Alfano et al. (2012) working with olive cake compost; by Salem et al. (2012) evaluating the compost produced from tree leaves and wood; by Ghini et al. (2007) and Bettiol et al. (2009) with sewage sludge; Bettiol et al. (2009) with fish hydrolyzate; Ureba et al. (2005) with chiken manure; Kouki et al. (2012) with compost from plant residues and Posidonia oceanica; and Yogev et al. (2006) with a mixture of residues.

The aim of the present study was to evaluate the suppressiveness of Pinus bark-based substrates supplemented with organic residues (composted sewage sludge, biofertilizer and fish hydrolyzate) and Trichoderma asperellum to control wilt caused by Fusarium oxysporum f. sp. crysanthemi in chrysanthemum. In addition, the induction of resistance in plants treated with chitosan on the aerial portion was evaluated.

\section{MATERIAL AND METHODS}

The experiments were performed with the hardy garden mum (known in Brazil as "bola-belga") chrysanthemum (Chrysanthemum morifolium) cultivar Papyrus White on a property specialized in chrysanthemum production in Holambra/SP, Brazil. Crop management was performed according to the producer's standard practices, and the plants were monitored for 20 weeks, from the planting of plantlets produced by the rooting of cuttings to the final evaluation. The plants were grown in plastic pots containing $3.3 \mathrm{~L}$ of substrate, with one plant per pot. In the first week after transplanting, irrigation was performed with water only and, during the following 19 weeks, via fertigation ( $0.5 \mathrm{~g} \mathrm{~L}^{-1}$ calcium nitrate; $0.6 \mathrm{~g} \mathrm{~L}^{-1} \mathrm{NPK} 5-30-15$; $0.6 \mathrm{~g} \mathrm{~L}^{-1}$ potassium sulfate; $0.25 \mathrm{~g} \mathrm{~L}^{-1}$ magnesium sulfate and $0.25 \mathrm{~g} \mathrm{~L}^{-1}$ ammonium nitrate). During the first 10 weeks (vegetative stage), the plants were maintained in an environment with a light regime of over 15 hours/day and were then transferred to an environment with a photoperiod of less than 12 hours/day (generative phase). Fertigation was automated and localized in the pot, and was performed three to four times per day.

The substrate used in the tests was obtained from pots containing the substrate Multiplant ${ }^{\circledR}(\mathrm{pH} 5.5$; EC 0.6 $\mu \mathrm{S} \mathrm{cm} \mathrm{cm}^{-1}$ ) with chrysanthemum plants that were diseased or killed by Fusarium. In the experiments, no artificial infestation was performed on the substrates with Fusarium because the pathogen was recovered from the pots with diseased plants and because both the water and irrigation systems were also naturally infested with the pathogen. This infestation was verified by plating samples of plants and irrigation water as well as parts of the vases and irrigation systems on Komada's medium, along with microscopic observation of pathogen structures. The pathogen population was estimated as $5 \times 10^{3} \mathrm{CFU} / \mathrm{mL}$ of the substrate by plating on Komada's medium.

Half the volume of the substrate was disinfested using steam treatment for approximately $12 \mathrm{~h}$ at $80^{\circ} \mathrm{C}$, and the other half was not disinfested. Subsequently, in a factorial design, composted sewage sludge with and without heat treatment obtained from the sewage treatment plant in Jundiaí/SP, Brazil was incorporated into the substrate at concentrations of $0 \%, 10 \%, 20 \%$ and $30 \%(\mathrm{v} / \mathrm{v})$. These mixtures were or were not treated with biofertilizer (Machado \& Bettiol, 2010) at $14 \mathrm{~mL} \mathrm{~L}^{-1}$ (Table 1) and a Trichoderma asperellum [SF04 (URM-5911) - Quality WG - Laboratório de Biocontrole Farroupilha Ltda] suspension with $10^{8}$ conidia

TABLE 1 - Chemical and physical attributes of sewage sludge, biofertilizer and fish hydrolyzate added to the pine bark-based substrate for inducing suppressiveness to Fusarium wilt in chrysanthemum

\begin{tabular}{|c|c|c|c|c|}
\hline ATTRIBUTE & & Sewage sludge & Biofertilizer & Fish hydrolyzate \\
\hline $\mathrm{pH}$ & \multirow{9}{*}{$\mathrm{g} \mathrm{kg}^{-1}$ or $\mathrm{g} \mathrm{L}^{-1}$} & 4.5 & 4.9 & - \\
\hline $\mathrm{N}$ & & 26.2 & 0.7 & 11.5 \\
\hline $\mathrm{P}$ & & 10.7 & 0.1 & 23.0 \\
\hline $\mathrm{K}$ & & 1.7 & 0.1 & - \\
\hline $\mathrm{Ca}$ & & 2.3 & 0.2 & 11.5 \\
\hline $\mathrm{Mg}$ & & 0.9 & 0.1 & - \\
\hline $\mathrm{S}$ & & 6.4 & 0.1 & - \\
\hline $\mathrm{C}$ & & 264.6 & 41.1 & 207 \\
\hline $\mathrm{Fe}$ & & 45.4 & 402.5 & 2.88 \\
\hline B & \multirow{4}{*}{$\mathrm{mg} \mathrm{kg}^{-1}$} & 58.0 & 0.01 & - \\
\hline $\mathrm{Cu}$ & & 1058.0 & 15.0 & - \\
\hline $\mathrm{Mn}$ & & 82.4 & 7.5 & 0.58 \\
\hline $\mathrm{Zn}$ & & 123.4 & 30.0 & - \\
\hline Moisture & $(\%)$ & 14.6 & 99.6 & - \\
\hline $\mathrm{C} / \mathrm{N}$ ratio & & 10.1 & 58.7 & 18.0 \\
\hline
\end{tabular}


$\mathrm{mL}^{-1}$ applied at $200 \mathrm{~mL}$ per pot. The substrates obtained were placed in $3.3 \mathrm{~L}$ pots for the subsequent planting of chrysanthemum plantlets. After transplanting, half of the pots in each treatment had their aerial portions sprayed weekly with chitosan at a concentration of $200 \mathrm{mg} \mathrm{L}^{-1}$ for 10 weeks. A second similar experiment was conducted with the same treatments, replacing only the biofertilizer with fish hydrolyzate (Fishfertil ${ }^{\circledR}$ - Table 1) at $10 \mathrm{~mL} \mathrm{~L}^{-1}$.

Assessment of Fusarium wilt severity was conducted using the disease scale proposed by Pinto et al. (2010), in which $0=$ healthy plant, $1=$ plant with slightly darkened vascular tissues in the central stem, 2 = plant with fully darkened vascular tissues in the central stem, $3=$ plant with the vascular tissues in the central stem fully darkened and at least one darkened vascular tissue in the secondary stem, $4=$ plant with wilt symptoms and with all vascular tissues darkened and $5=$ dead plant. Severity assessments were destructive and performed at $8,12,15$ and 20 weeks after planting; five plants were evaluated for each treatment at every one of these stages. Thus, at every stage, the experiments contained 32 treatments with 20 replicates each, totaling 640 pots per test at every stage. To confirm the presence of the pathogen in the plants, plating was performed using stem fragments on Komada's medium for further observation of the fungal structures under a light microscope, and a pathogenicity test was conducted thereafter.

At 12 weeks after planting, the community of fluorescent bacteria and fungi present in the rhizosphere of the chrysanthemum plants was assessed. For this purpose, one-gram aliquots of the substrate from the rhizosphere, representative of each treatment, were collected and added to $9 \mathrm{~mL}$ sterile distilled water for performing serial dilutions to a concentration of $10^{-5}$. In Petri dishes containing culture medium divided into quadrants, four $10 \mu \mathrm{L}$ aliquots were deposited into each quadrant, corresponding to one dilution. The plates were maintained at $24 \pm 3^{\circ} \mathrm{C}$. The evaluation was performed by counting the number of colonies originating from each drop after $24 \mathrm{~h}$ for bacteria and after three days for fungi. The medium used for the bacteria and fungi counts was King B and Martin, respectively. In the same week, the total microbial activity of the substrate was determined by the hydrolysis of fluorescein diacetate (FDA) (Boehm and Hoitink, 1992) and the chemical attributes of the substrates $(\mathrm{pH}$, electrical conductivity $(\mathrm{EC})$, macroand micronutrients) with extraction 1:1.5 (substrate:water) (Sonneveld et al., 1994) were evaluated.

The experiments a complete randomized 4-factorial design [4 (sludge doses) $\times 2$ (with and without biofertilizer or fish hydrolyzate) $\times 2$ (with and without Trichoderma) x 2 (with and without chitosan)] with 20 replicates. The results of severity obtained at the four assessment dates were used to calculate the area under the disease progress curve (AUDPC) using the Sigma Plot 10.0 software. Statistical analyses of the data were performed using SAS software (SAS Institute). Statistical analyses of the FDA, microbial community of fungi and bacteria, $\mathrm{pH}$ and EC (Table 2) and chemical characteristics (Table 3) data were performed using SISVAR software (Ferreira, 2000). We compared the effect of disinfestation, and the addition of sewage sludge, associated or not with biofertilizer (B) and fish hydrolyzate $(\mathrm{H})$ on chemical and biological characteristics of the substrates, by Tukey test $(P>0.05)$. Interaction of effect of each factor level in the presence/absence of the other factors was studied. For dose of sewage sludge we performed regression analysis.

\section{RESULTS}

The incorporation of composted sewage sludge to the pine bark-based substrate significantly reduced Fusarium wilt in chrysanthemum (Figure 1). The AUDPC generally decreased as the concentration of sewage sludge increased. When biofertilizer, fish hydrolyzate, and T. asperellum where incorporated into the substrate either alone or in combination, disease severity (AUDPC) was not reduced. In the presence of composted sewage sludge, regardless of the concentration, none of the supplements provided further disease reduction. The application of chitosan to the aerial part of the plant had no effect on the severity of Fusarium wilt in the different substrates (Figure 1).

Heat-treated substrates showed significantly lower microbial activity than the untreated, regardless of the sewage sludge concentration, as noticed by analyzing both FDA hydrolysis and the fungal community (Table 2). The initial substrate disinfestation negatively influenced the induction of suppressiveness because there was an increase in AUDPC among plants grown in disinfested substrates independent of the other supplements incorporated (Figure 1). Biofertilizer, independent of heat-treatment, increase FDA hydrolysis (Table 2).

In the substrate supplemented with sewage sludge, a positive correlation was found between doses of sewage sludge and concentrations of calcium $(\mathrm{yH}=3.2925+$ $2.57425 \mathrm{x} ; \mathrm{r}^{2}=90.95 \%$, and $\mathrm{yB}=-3.33+4.0395 \mathrm{x} ; \mathrm{r}^{2}=88.56 \%$ ), magnesium $\left(\mathrm{yH}=3.445+0.73825 \mathrm{x} ; \mathrm{r}^{2}=96.24 \%\right.$, and $\left.\mathrm{yB}=3.3625+0.9125 \mathrm{x} ; \mathrm{r}^{2}=95.62 \%\right)$, sulphur $(\mathrm{yH}=11.865+$ $3.0065 x ; r^{2}=94.03 \%$, and $\left.y B=5.3825+4.3395 x ; r^{2}=90.20 \%\right)$, zinc $\left(\mathrm{yH}=0.030875-0.009787 \mathrm{x}+0.000669 \mathrm{x}^{2} ; \mathrm{r}^{2}=96.76\right.$, and $\left.\mathrm{yB}=-0.22325+0.0443 \mathrm{x} ; \mathrm{r}^{2}=73.80\right)$, and manganese $\left(\mathrm{y}=0.02925-0.01295 \mathrm{x}+0.000825 \mathrm{x}^{2} ; \mathrm{r}^{2}=94.52 \%\right.$, and $\left.\mathrm{yB}=0.05025-0.044225 \mathrm{x}+0.003262 \mathrm{x}^{2} ; \mathrm{r}^{2}=98.29 \%\right)($ Table 3 ). In the treatments with sewage sludge, nitrate- $\mathrm{N}$ generally prevailed. There were no consistent alterations in relation to the chemical characteristics of the substrates, sterilized or non-sterilized, treated with biofertilizer and fish hydrolyzate (Table 3).

\section{DISCUSSION}

The composted sewage sludge incorporated into the substrate was the main cause for the induction of 


\begin{tabular}{|c|c|c|c|c|c|c|c|c|c|c|}
\hline \multirow[t]{2}{*}{ Treatment } & \multicolumn{2}{|c|}{ FDA ( $\mu \mathrm{g} \mathrm{g}^{-1}$ of dry substrate) } & \multicolumn{2}{|c|}{ Fungi CFU $\left(10^{4} \mathrm{~g}^{-1}\right)$} & \multicolumn{2}{|c|}{ Bacteria CFU $\left(10^{6} \mathrm{~g}^{-1}\right)$} & \multicolumn{2}{|c|}{ pH } & \multicolumn{2}{|c|}{$E C\left(d S m^{-1}\right)$} \\
\hline & $\mathbf{S}$ & NS & $\mathbf{S}$ & NS & $\mathbf{S}$ & NS & $\mathbf{S}$ & NS & $\mathbf{S}$ & NS \\
\hline \multicolumn{11}{|c|}{ Biofertilizer } \\
\hline B & 6.52 & 7.37 & 1.0 & 6.2 & 32.0 & 15.6 & 6.2 & 6.4 & 0.3 & 0.3 \\
\hline Control & 3.16 & 7.73 & 0.2 & 5.9 & 6.9 & 7.0 & 5.9 & 5.8 & 0.3 & 0.3 \\
\hline SS $10 \%+B$ & 5.98 & 6.74 & 1.2 & 6.0 & 14.0 & 21.0 & 6.0 & 5.9 & 0.4 & 0.4 \\
\hline SS $10 \%$ & 4.47 & 6.33 & 1.2 & 5.9 & 5.2 & 23.7 & 5.4 & 5.0 & 0.6 & 0.8 \\
\hline SS $20 \%+B$ & 4.98 & 5.87 & 1.3 & 6.0 & 8.0 & 25.1 & 5.3 & 5.3 & 0.6 & 0.6 \\
\hline SS $20 \%$ & 4.61 & 6.78 & 1.2 & 6.7 & 6.2 & 25.5 & 5.2 & 4.6 & 0.9 & 1.8 \\
\hline SS $30 \%+B$ & 6.34 & 5.60 & 2.1 & 6.7 & 12.0 & 24.9 & 5.0 & 4.6 & 0.8 & 1.1 \\
\hline SS $30 \%$ & 4.89 & 5.44 & 1.8 & 6.6 & 5.2 & 24.2 & 6.2 & 6.2 & 0.3 & 0.3 \\
\hline Mean & $5.12 \mathrm{~b}$ & $6.48 \mathrm{a}$ & $1.25 \mathrm{~b}$ & $6.25 \mathrm{a}$ & $11.19 \mathrm{a}$ & $20.87 \mathrm{a}$ & $5.65 \mathrm{a}$ & $5.47 \mathrm{a}$ & $0.52 \mathrm{a}$ & $0.7 \mathrm{a}$ \\
\hline $\mathrm{CV}$ & \multicolumn{2}{|c|}{19.06} & \multicolumn{2}{|c|}{7.81} & \multicolumn{2}{|c|}{55.34} & \multicolumn{2}{|c|}{3.38} & \multicolumn{2}{|c|}{36.38} \\
\hline \multicolumn{11}{|c|}{ Fish hydrolyzate } \\
\hline $\mathrm{H}$ & 1.31 & 3.51 & 1.2 & 5.92 & 3.2 & 6.1 & 6.4 & 6.6 & 0.2 & 0.2 \\
\hline Control & 1.57 & 3.27 & 1.5 & 5.36 & 2.7 & 3.9 & 6.2 & 6.4 & 0.2 & 0.3 \\
\hline SS $10 \%+\mathrm{H}$ & 2.25 & 2.84 & 3.1 & 3.1 & 1.8 & 6.2 & 6.2 & 5.9 & 0.2 & 0.5 \\
\hline SS $10 \%$ & 1.77 & 3.59 & 1.9 & 2.8 & 0.6 & 3.8 & 5.9 & 6.2 & 0.5 & 0.3 \\
\hline SS $20 \%+H$ & 1.93 & 3.18 & 0.1 & 7.1 & 2.7 & 3.5 & 5.7 & 5.4 & 0.4 & 0.6 \\
\hline SS $20 \%$ & 1.97 & 2.95 & 1.9 & 6.10 & 1.6 & 2.9 & 5.7 & 5.8 & 0.4 & 0.7 \\
\hline SS $30 \%+H$ & 2.06 & 3.38 & 2.2 & 13.2 & 2.3 & 5.1 & 5.0 & 5.0 & 1.0 & 0.8 \\
\hline SS $30 \%$ & 2.44 & 2.84 & 1.9 & 12.0 & 1.2 & 5.3 & 5.2 & 5.1 & 0.7 & 1.0 \\
\hline Mean & $1.91 \mathrm{~b}$ & $3.20 \mathrm{a}$ & $1.72 \mathrm{~b}$ & $6.95 \mathrm{a}$ & $2.01 \mathrm{~b}$ & $4.60 \mathrm{a}$ & $5.79 \mathrm{a}$ & $5.80 \mathrm{a}$ & $0.45 \mathrm{a}$ & $0.55 \mathrm{a}$ \\
\hline $\mathrm{CV}$ & & & & & & & & & & \\
\hline
\end{tabular}

Within each characteristics of substrates $\mathrm{S}$ and NS, means followed the same letter are not significantly different (Tukey alfa at $\mathrm{P}=0.05$ ). 
TABLE 3 - Chemical characteristics of the pine bark-based substrate (Control-C), sterilized or non-sterilized by steam and supplemented with sewage sludge (SS) plus biofertilizer (B) or fish hydrolyzate $(\mathrm{H})$ in the first and second experiments, respectively

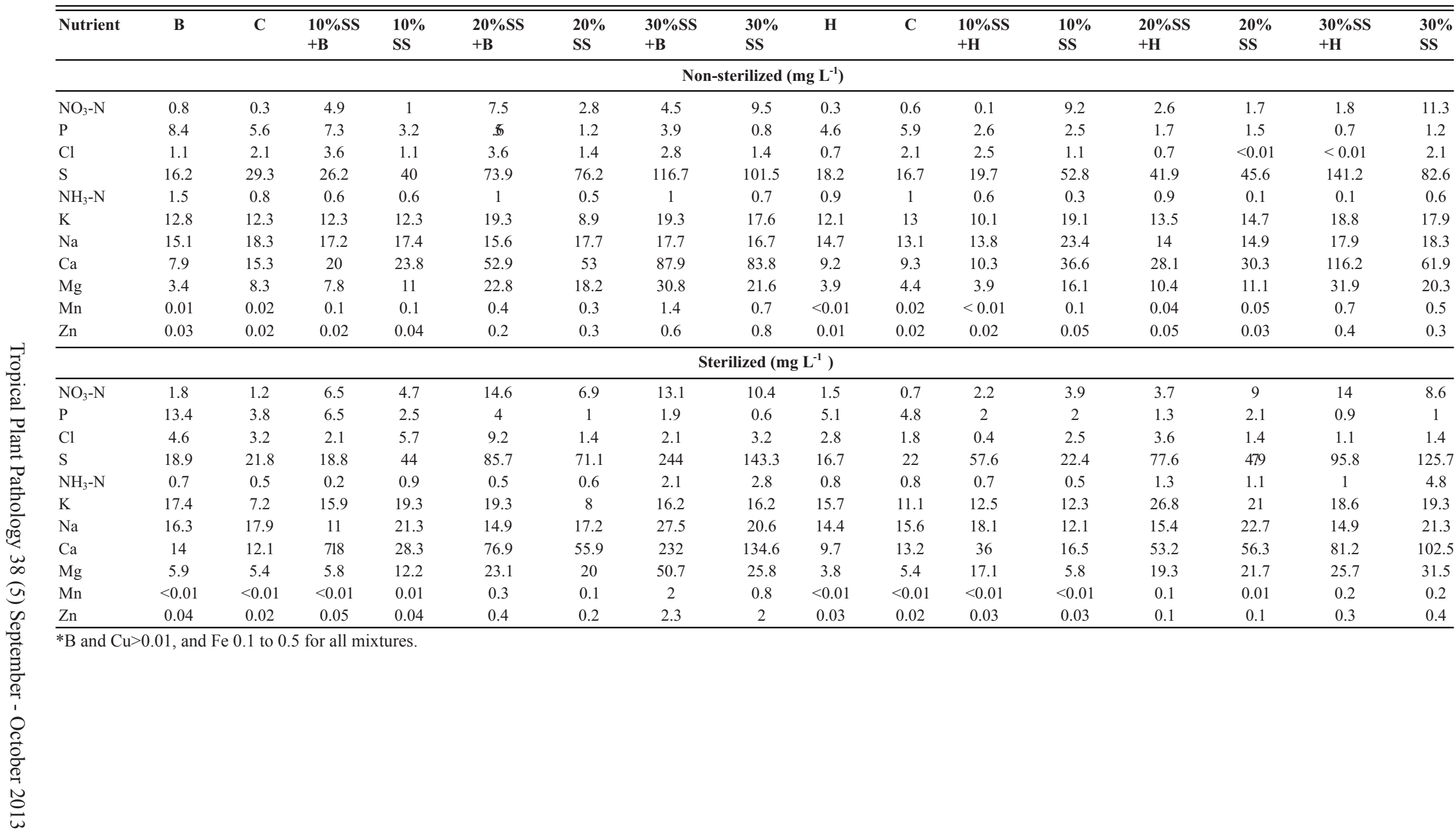



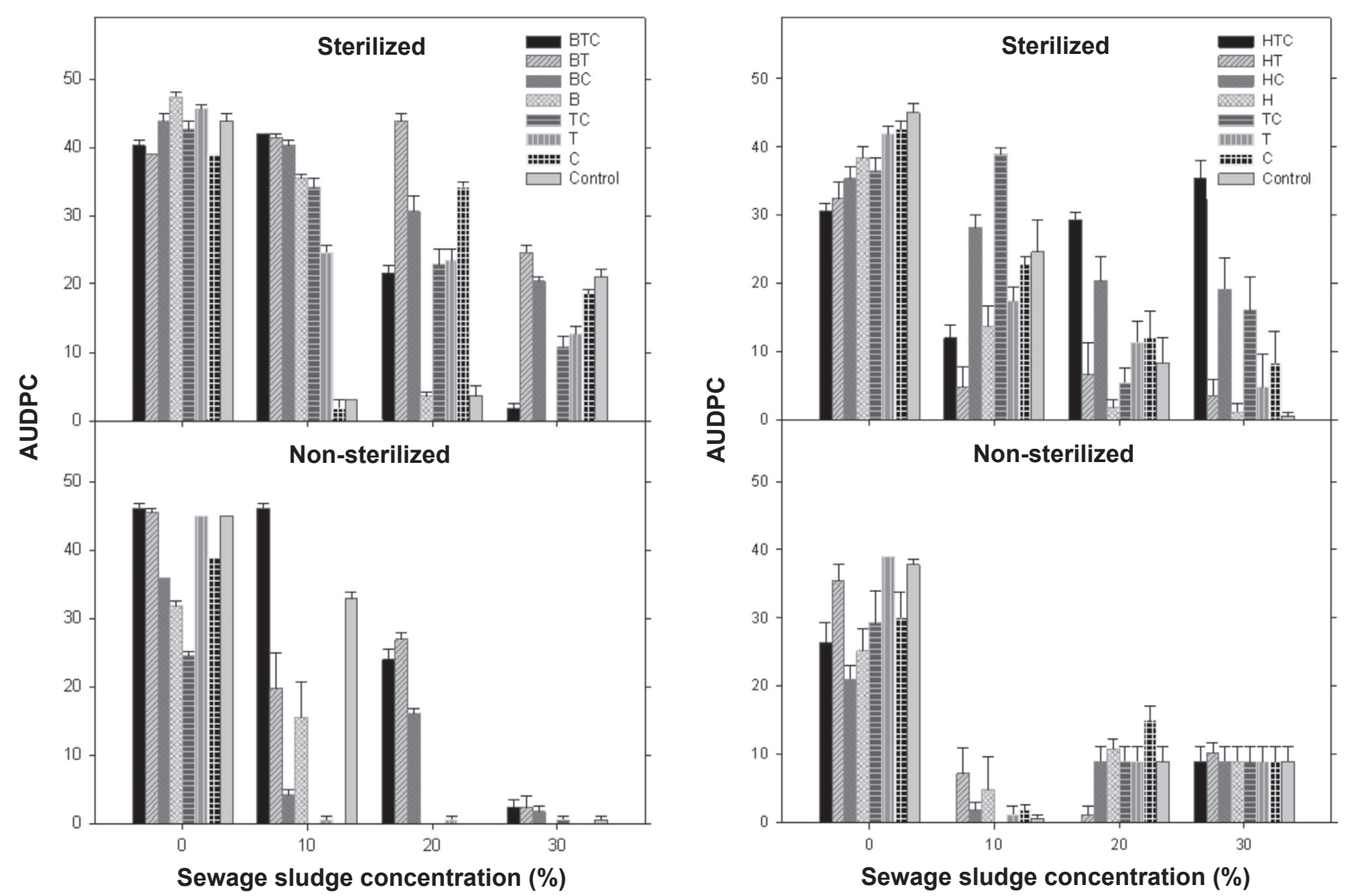

FIGURE 1 - Effect of the disinfestation of pine bark-based substrate (PB), which was naturally infested with Fusarium, on the induction of suppressiveness by composted sewage sludge in combination with biofertilizer (B), fish hydrolyzate (H), Trichoderma asperellum (T) and chitosan (C) on the area under the disease progress curve (AUDPC) of Fusarium wilt in chrysanthemum. The standard errors from each treatment of experiments $1(\mathrm{~B})$ and $2(\mathrm{H})$ are presented.

suppressiveness against Fusarium, independent of the substrate disinfestation or supplementation with fish hydrolyzate, biofertilizer, Trichoderma or chitosan. These observations highlight the ability of composted sewage sludge to alter the biological, physical and chemical characteristics involved in the suppressiveness to Fusarium. Ghini et al. (2007) obtained similar results when studying the effect of raw (not composted) sewage sludge for the control of Rhizoctonia solani and Ralstonia solanacearum, whereas Santos \& Bettiol (2003) and Cotxarrera et al. (2002) observed suppression of Sclerotium rolfsii and Fusarium wilt, respectively with composted sewage sludge.

The induction of suppressiveness with the incorporation of sewage sludge should be mainly attributed to biological factors because the microbial activity and fungal and bacterial communities were greater in the substrates not thermally disinfested, which also correlated with greater suppressiveness. The increased microbial activity induced by the incorporation of sewage sludge and other organic residues was also observed by Chen et al. (1988), Dissanayake \& Hoy (1999), Cotxarrera et al.
(2002), Santos \& Bettiol (2003), Abbasi et al. (2004), Ghini et al. (2007) and Lazarovits et al. (2009).

Several authors have discussed the need to incorporate organic matter that stimulates the maintenance of microbial activity to obtain a substrate suppressive to soil-borne pathogens (Hoitink \& Fahy, 1986; Chen et al., 1988; and Hoitink \& Boehm, 1999). Visconti et al. (2010) found that the increased microbial activity in substrates treated with $20 \%$ fish hydrolyzate was responsible for the induction of suppressiveness to Cylindrocladium spathiphylli in Spathiphyllum. In addition to increased soil microbial activity, as determined by analyses of specific enzymes and soil respiration, the changes in the overall microbial community of the soil are also important. Postma et al. (2008) observed that some species of the soil microbial community are associated with suppressiveness, and this observation was verified by Lazarovits et al. (2009), who also found that the species composition changed with the incorporation of organic matter.

Associated with the soil microbial activity, the release of volatile fatty acids, both those present in organic residues and those released by the degradation of organic matter, is 
also responsible for the induction of suppressiveness. This mechanism is amply discussed by Abbasi et al. (2004), Conn et al. (2007) and Lazarovits et al. (2009) and may also be associated with the incorporation of the sewage sludge compost, as there is a release of volatile fatty acids during sewage and sludge decomposition (Yang et al., 2012). In the substrate used, there is a possibility that this production of volatile fatty acids occurs throughout the crop cycle, as the sludge has a low carbon:nitrogen $(\mathrm{C}: \mathrm{N})$ ratio, while pine bark has a high ratio (Table 1).

Thermorshuizen et al. (2006) studied the suppressiveness of 18 substrate components against seven pathosystems and indicated that higher suppressiveness occurs when using a mixture rather than one component alone. The diverse composition of sewage sludge may have contributed to the observed results.

The heat treatment most likely eliminated the entire microbial community from the substrate, creating a biological vacuum, which did not occur in the nondisinfested substrate. Similar results, although in a study using fish emulsion, were obtained by Abbasi et al. (2004), who observed that pasteurizing the substrate resulted in a greater occurrence of Rhizoctonia in radish than in the unpasteurized substrate. These authors also found a reduction in the microbial community with the pasteurization of the substrate. These data demonstrate the biological nature of the suppressiveness induced by sewage sludge compost.

The aspects related to nutrition are of great importance regarding disease severity in plants (Engelhard, 1990). The substrate to which the sewage sludge was incorporated showed an overall increase in concentrations of nitrate-N, potassium, calcium, magnesium, sulphur and manganese, nutrients related to the occurrence of Fusarium in soils (Engelhard, 1990; Huber, 1994). In addition to the concentration, the form in which these nutrients are available is also important. Generally, the occurrence of diseases caused by Fusarium is reduced when nitrogen, which predominates in the soil, is in the form of nitrate-N and increased when present as ammonia-N. The form of nitrogen is related to $\mathrm{pH}$, i.e., the disease is most severe when the $\mathrm{pH}$ is acidic and when ammonia is present (Huber, 1994). In treatments with sewage sludge, nitrate- $\mathrm{N}$ generally predominated. In the treatments with sewage sludge in which the pathogen was controlled, greater concentrations of sulfur and calcium were generally observed. Calcium is related to the integrity of the cell wall and membrane, which are physical barriers that the pathogen must face to penetrate and establish itself in the plant.

The electric conductivity (EC) values obtained did not explain the induction of suppressiveness by the sewage sludge, as there was no significant difference among the treatments. However, several authors found a correlation between the electrical conductivity of soil and suppressiveness to diseases (Amir \& Alabouvette, 1993; Santos \& Bettiol, 2003). Nevertheless, the importance of its variation along the cycle cannot be dismissed because the analysis of the EC was performed only halfway through growth.

In the present study, no reduction in the severity of Fusarium wilt was observed with the application of chitosan, a substance known to induce plant resistance to different pathogens in several pathosystems (Coqueiro et al., 2011).

As discussed and shown in the analysis, the induction of suppressiveness observed with the addition of sewage sludge to the pine bark-based substrate must not only be related to a single characteristic altered in the substrate, as there were significant changes in the microbial activity, nutrient concentration and $\mathrm{pH}$ of the substrate. Although not evaluated in the present study, evidences that changes in microbial composition and production of volatile compounds in the substrates probably contributed to the observed suppressiveness. These hypotheses are been investigated. The contribution of each factor alone in the induction of suppressiveness cannot be quantified using the findings of the present study. However, they constitute additional evidence of the efficiency of sewage sludge compost in controlling Fusarium wilt on chrysanthemum. Moreover, because the sewage sludge is rich in many macro- and micronutrients, it allows for the reduction in the amount of nutrients applied via fertigation.

Suppressiveness induced by composted sewage sludge was maintained through the last evaluation, i.e., up to the $20^{\text {th }}$ week of plant development. This prolonged effect is an important practical aspect because plants are commercialized at 16 weeks, and at the end of the cycle due to intense flowering they become more susceptible to the pathogen. Thus, plants grown on substrates supplemented with sewage sludge were within the standard for commercialization until the end of their cycle (data not shown).

\section{ACKNOWLEDGEMENTS}

The authors thank the Agricultural Engineer Adrianus Pfening for providing the facilities on his property for conducting the experiment. The authors Zayame Vegette Pinto and Wagner Bettiol thank the National Council of Technological and Scientific Development (Conselho Nacional de Desenvolvimento Científico e Tecnológico - $\mathrm{CNPq}$ ) for providing the doctorate and productivity fellowships, respectively.

\section{REFERENCES}

Abbasi PA, Conn KL, Lazarovits G (2004) Suppression of Rhizoctonia and Pythium damping-off of radish and cucumber seedlings by addition of fish emulsion to peat mix or soil. Canadian Journal of Plant Pathology 26:177-187.

Alabouvette C (1999) Fusarium wilt suppressive soils: an example of disease-suppressive soils. Australasian Plant Pathology 28:5764.

Tropical Plant Pathology 38 (5) September - October 2013 
Alfano G, Lustrato G, Lima G, Vitullo D, Ranalli G (2012) Characterization of composted olive mill wastes to predict potential plant disease suppressiveness. Biological Control 58:199-207.

Amir H, Alabouvette C (1993) Involvement of soil abiotic factors in the mechanisms of soil suppressiveness to Fusarium wilts. Soil Biology and Biochemistry 25:157-164.

Bailey KL, Lazarovits G (2003) Suppressing soil-borne diseases with residue management and organic amendments. Soil \& Tillage Research 72:169-180.

Baker KF, Cook RJ (1974) Biological control of plant pathogens. San Francisco CA, USA. Freeman.

Bettiol W, Ghini R, Mariano RRL, Michereff S, Mattos LV, Alvarado ICM, Pinto ZV (2009) Supressividade à fitopatógenos habitantes do solo. In: Bettiol W, Morandi MAB (Eds.) Biocontrole de doenças de plantas: Uso e perspectivas. Jaguariúna SP, Brazil. Embrapa Meio Ambiente. pp. 187-208.

Blum LEB, Rodriguez-Kabana R (2004) Effect of organic amendments on sclerotial germination, mycelial growth, and Sclerotium rolfsii-induced diseases. Fitopatologia Brasileira 29:66-74.

Boehm MJ, Hoitink HAJ (1992) Sustenance of microbial activity in potting mixes and its impact on severity of Pythium root rot of poinsettia. Phytopathology 82:259-264.

Chef DG, Hoitink HAJ, Madden LV (1983) Effects of organic components in container media on suppression of Fusarium wilt of chrysanthemum and flax. Disease Control and Pest Management 73:279-281.

Chen WD, Hoitink HAJ, Schmitthenner AF, Tuovinen OH (1988) The role of microbial activity in suppression of damping-off caused by Pythium ultimum. Phytopathology 78:314-322.

Coqueiro DSO, Maraschin M, Piero RMD (2011) Chitosan reduces bacterial spot severity and acts in phenylpropanoid metabolism in tomato plants. Journal of Phytopathology 159:488-494.

Conn KL, Lazarovits G (1999) Impact of animal manures on Verticillium wilt, potato scab, and soil microbial populations. Canadian Journal of Plant Pathology 2:81-92.

Conn KL, Tenuta M, Lazarovits G (2005) Liquid swine manure can kill Verticillium dahliae microsclerotia in soil by volatile fatty acid, nitrous acid, and ammonia toxicity. Phytopathology 95:2835 .

Conn KL, Topp E, Lazarovits G (2007) Factors influencing the concentration of volatile fatty acids, ammonia, and other nutrients in stored liquid pig manure. Journal of Environmental Quality 24:440-447.

Cotxarrera L, Trillas-Gay MI, Steinberg C, Alavouvette C (2002) Use of sewage sludge compost and Trichoderma asperellum isolates to suppress Fusarium wilt of tomato. Soil Biology and Biochemistry 34:467-476.

Dissanayake N, Hoy JW (1999) Organic material soil amendment effects on root rot and sugarcane growth and characterization of the materials. Plant Disease 83:1039-1046.

Engelhard AW (1990) Soilborne plant pathogens: Management of diseases with macro-and microelements. St. Paul MN, USA. APS Press.

Ferreira DF (2000) SISVAR: Software para análises estatísticas. Lavras MG, Brazil. UFLA/DEX.
Ghini R, Patrício FRA, Bettiol W, Almeida IMG, Maia AHN (2007) Effect of sewage sludge on suppressiveness soil-borne plant pathogens. Soil Biology \& Biochemistry 39:2797-2805.

Hoitink HAJ, Fahy PC (1986) Basis for the control of soilborne plant pathogens with composts. Annual Review of Phytopathology 24:93-114

Hoitink HAJ, Boehm MJ (1999) Biocontrol within the context of soil microbial communities: A substrate-dependent phenomenon. Annual Review of Phytopathology 37:427-446.

Hoper H, Alabouvette C (1996) Importance of physical and chemical soil properties in the suppressiveness of soils to plant diseases. European Journal of Soil Biology 32:41-58.

Huber DM (1994) The influence of mineral nutrition on vegetable diseases. Horticultura Brasileira 12:206-214.

Kouki S, Saidi N, Ben Rajeb A, Brahmi M, Bellila A, Fumio M, Hefiène A, Jedidi N, Downer J, Ouzari H (2012) Control of Fusarium wilt of tomato caused by Fusarium oxysporum f. sp. radicis-lycopersici using mixture of vegetable and Posidonia oceanica compost. Applied and Environmental Soil Science 2012:1-11.

Lazarovits G, Abbasi PA, Conn KL, Hill JE, Hemmingsen JE (2009) Fish emulsion and liquid swine manure: Model systems for development of organic amendments as fertilizers with disease suppressive properties. In: Bettiol W, Morandi MAB (Eds.) Biocontrole de doenças de plantas: Uso e perspectivas. Jaguariúna SP, Brazil. Embrapa Meio Ambiente. pp. 49-67.

Machado MADF, Bettiol W (2010) Potencial para o biocontrole de Botrytis cinerea por leveduras em sistema integrado de cultivo de lírio. Pesquisa Agropecuária Brasileira 45:539-545.

Mendes R, Kruijit M, Bruijn I, Dekkers E, Van der Voort M, Scheneider JHM, Piceno YM, DeSantis TZ, Andersen GL, Bakker PAHM, Raaijmakers JM (2011) Deciphering the rhizosphere microbiome for disease-suppressive bacteria. Science 332:10971100 .

Pane C, Spaccini R, Piccolo A, Scala F, Bonanomi G (2011) Compost amendments enhance peat suppressiveness to Pythium ultimum, Rhizoctonia solani and Sclerotinia minor. Biological Control 56:115-124.

Pinto ZV, Bettiol W, Morandi MAB (2010) Efeito de casca de camarão, hidrolisado de peixe e quitosana no controle da murcha de Fusarium oxysporum f. sp. chrysanthemi em crisântemo. Tropical Plant Pathology 35:16-23.

Postma J, Schilder, MT, Bloem J, van Leeuwen-Haagsma WK (2008) Soil suppressiveness and functional diversity of the soil microflora in organic farming systems. Soil Biology \& Biochemistry 40:2394-2406.

Salem WM, Sayed WF, Abdel-Fatah H, Neamat HH (2012) Assessment of compost for suppression of Fusarium oxysporum and improving Zea mays and Hibiscus sabdarriffa resistance to wilt diseases. African Journal of Biotechnology 11:13403-13414.

Santos I, Bettiol W (2003) Effect of sewage sludge on the rot and seedling damping-off of bean plants caused by Sclerotium rolfsii. Crop Protection 22:1093-1097.

Sonneveld C, Van Elderen CW (1994) Chemical analysis of peaty growing media by means of water extraction. Communications in Soil Science and Plant Analysis 25:3199-3208.

Tenuta M, Conn KL, Lazarovits G (2002) Volatile fatty acids in 
liquid swine manure can kill microsclerotia of Verticillium dahliae. Phytopathology 92:548-552.

Thermorshuizen AJ, Van Rijn E, Vander Gaag DJ, Alabouvette C, Chen Y, Lagerlof J, Malandrakis AA, Paplomatas EJ, Ramert B, Ryckeboer J, Steinberg C, Zmora-Nahum S (2006) Suppressiveness of 18 composts against 7 pathosystems: Variability in pathogen response. Soil Biology \& Biochemistry 38:2461-2477.

Ureba MJB, Rodríguez ML, Herrera JMMV, Ligero AMP (2005) Utilización de enminedas orgánicas y cultivo hidropónico en el control de la fusariosis del clavel. Elucía España. Consejería de Agricultura y Pesca.

Visconti A, Bettiol W, Morandi MAB (2010) Efeito de hidrolisado de peixe sobre o crescimento micelial e controle de Cylindrocladium spathiphylli em espatifilo. Summa Phytopathologica 36:298-308.

Yang X, Du M, Lee D, Wan C, Zheng L, Wan F (2012) Improved volatile fatty acids production from proteins of sewage sludge with anthraquinone-2, 6-disulfonate (AQDS) under anaerobic condition. Bioresource Technology 103:494-497.

Yogev A, Raviv M, Hadar Y, Cohen R, Katan J (2006) Plant wastebased composts suppressive to diseases caused by pathogenic Fusarium oxysporum. European Journal of Plant Pathology 116:267-278.

Zmora-Nahum S, Danon M, Hadar Y, Chen Y (2008) Compost curing reduces suppression of plant diseases. Compost Science \& Utilization 14:250-256. 